\title{
Czech and Slovak museology, current status and the future of this branch of science
}

JAN DOLÁK*

The first person to use the term "museology" in the Czech environment seems to have been Mr. Kliment Cermák, teacher and museologist, who for the first time formulated a need for special education to be provided for museum workers in his article Education in $\mathrm{Mu}-$ seology from 1901 published under his editorship in the Bulletin of Czech \& Slavonic Archaeological and Museum Association. His publication activities were continued by V. V. Jenícek in the magazine "Czech \& Slavonic Museum Annals" between 1902 and 1910 and by Albín Stocký in the magazine "Museum Horizon" published between 1925 and 1928. In Slovakia, there were A. Kmet' and F. Sasinek, and later P. Kri ko, M. Rybecký, A. Gregorová and M. Lalkovic, standing at the beginning and formation of museology. This generation, and for the most part also the following generation, were on a level comparable with the European elite but they published mainly in the Czech language, therefore they remained more or less hidden from the rest of the world. Museology undoubtedly has a long tradition in Central Europe and this paper aims to reflect the present status and key issues in the environment of the former Czechoslovakia.

Lectureships in Museology established at the University in Brno in 1921 thanks to Jaroslav
Helfert, a leading Moravian museologist, can be considered as the first comprehensive educational programme focused on museography. After World War II, museology was cultivated in Prague, particularly by J. Neustupný, and later J. Beneš and J. Špét. Proper teaching of museology was launched in 1965 at a newly established site in the Faculty of Arts, Brno University, in close cooperation with the Moravian Museum in Brno, founded by the later ICOM President J. Jelínek, and Z. Z. Stránský, when in particular the latter became a leading museology theorist within at least the Central European area. Brno played an important role in foundation and development of ICOM committees for museology (ICOFOM) and education of personnel (ICTOP). The magazine "Museology Sheets" issued in this period became a platform for the development of museology within the whole of Europe that could not be ignored. Besides scientific activities, this site provided museum staff with a university education, who needed to complete their knowledge in museology, with a three-year specialized study programme. This study was completed successfully by 226 candidates. The International Summer School of Museology established in Brno in 1987 has achieved an international reputation in a very short time. The school was proud to have a 
JAN DOLÁK

100

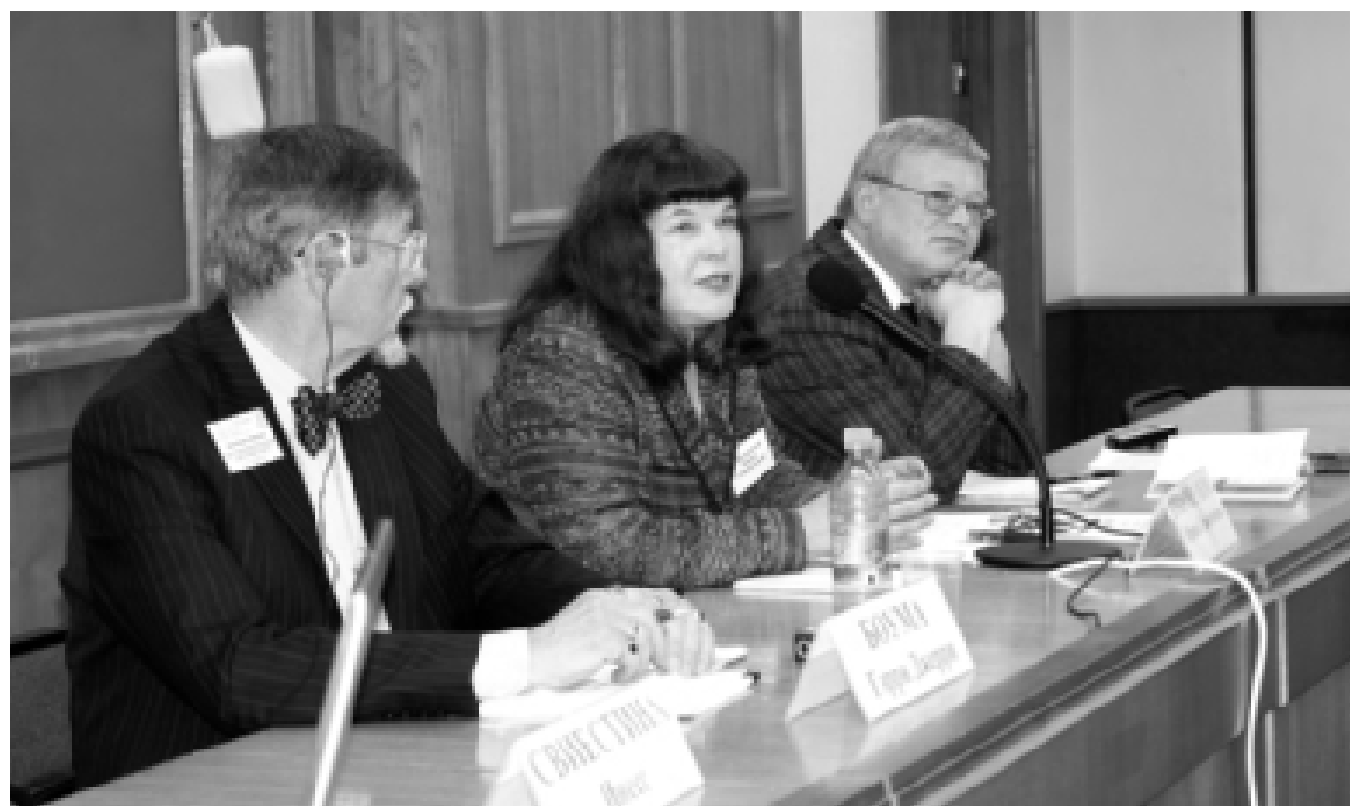

Fig. 1. Jan Dolák ( the first from right) as a leader of discussion panel in Moscow, conference "Intercultural and Interreligious dialogue for sustainable development", September 2007.

wide range of recognized teachers (among others, B. Deloche, P. v. Mench, I. Maroevic, K. Hudson, M. Schärer), as well as graduates from all over the world (An Laishun from China, M. Lalkovic from Slovakia, etc.).

The change of social and economical conditions in 1989/1990 caused a key breakthrough in the whole museum sphere. Museology was released from a uniform ideology and its development has unusually accelerated. It must be noted however, that the development was more quantitative than qualitative. Since 1993, regular Master's and Bachelor's studies of museology have been accredited at the Faculty of Arts in Brno with the options of fulltime study or study combined with another branch (most frequently with history, art history, but also pedagogy, psychology etc.). So far a total of 300 students have been enrolled for full time study, from which 171 have already graduated, in 73 cases with the Master's title. Combined study of museology has been entered by a total of 161 people, from which 24 have completed their studies with the title of Master and 45 with the title of Bachelor. Museology is also taught in Brno at the Faculty of Science. Eight of 14 students enrolled in museological biology and 37 of 76 students enrolled in geology and museology, have already graduated. ${ }^{1}$

New conditions were favourable enough to allow the establishment of an independent Department of Museology and habilitation of Z. Z. Stránský as a full college lecturer for this branch in 1993. Museology teaching and development in Brno as a scientific branch have 
been supported by a special branch of the UNESCO Chair of Museology and World Heritage since 1996.

At the Bachelor and Master level of study, study at the Silesian University in Opava has been accredited only if combined with history. There is a clear intention to establish the study of museology at the Faculty of Philosophy and Arts, Charles University in Prague. ${ }^{2}$ A museology course, with a volume in most cases of 2 semesters, is taught within the study programme of ethnology and art history at the Masaryk University in Brno, within the study programme of archaeology; and ethnology at the Faculty of Philosophy and Arts, Charles University in Prague, within the study programme of archaeology at the University of West Bohemia in Pilsen, within the study programme of history of culture at the University of East Bohemia in Pardubice, etc. A brief introduction to museology is presented in other academic locations, e.g. at the Mining and Metallurgy University - Technical University in Ostrava, within the study programme of Geoscience and Industrial Tourism and at higher specialized schools in Prague and Brno. From many training sessions, seminars and courses, the largest scope is recognized at the School of Museum Propedeutics, operated by the Association of Museums and Galleries of the Czech Republic, Prague, incl. extended studies. It can be summarized, that something like museology, museography or museum science is taught at 15 sites throughout the Czech Republic.

Despite the split of the Czechoslovak Republic into two states in 1992, the situation in Slovakia is very similar to the Czech Republic and educational programmes focused on museology are spread out all over the country. Fully accredited museology is taught at Con- stantine the Philosopher University in Nitra, in the Department of History, at Matej Bel University in Banska Bystrica, in the Faculty of Arts, Komensky University in Bratislava, Department of Ethnology and Cultural Anthropology (only Bachelor's study, so far), at the University in ilina and others. (Hrcka, Krišková 2006).

Quantitative development is clear proof that this branch of study is more attractive within the Central European area but there are some obvious obstacles, such as a lack of good teachers, material facilities and, primarily, development of museology as an independent peculiar science. Museology is not accredited at the third, doctorate level anywhere in the territory of the former Czechoslovakia. People who wish to commit themselves to museology and feel that it is their mission must achieve their academic qualification, i.e. titles such as $\mathrm{PhD}$., lecturer or professor, through other related studies. It is not therefore possible to be committed fully to museology as a main subject of interest and to just happen to become a professor of archaeology, ethnology or pedagogy, regardless of the fact that related branches of study can offer absolutely different conditions to young capable scientists for their personal development than the museology branch. We already "borrow" experts from other branches for the strict criteria for bachelor and master study accreditation. It is a vicious circle. We do not have enough qualified experts and due to that fact museology cannot be awarded a doctorate level of study; but how do we get such experts under such conditions?

Step by step, Czech and Slovak museologists have been overcoming the handicap of illiteracy in western world languages, but their publication activities in English or German, and even in Czech and Slovak, are not very out- 
102 standing. It is a little shaming that from the entire Czech museology community, the most productive author is eternally active, 81-year old Z. Z. Stránský, who regularly publishes his articles in the Munich journal "Museum Aktuell" and in other magazines (Stránský 2005).

Via facti, at the end of the 20th century, the prestigious International Summer School of Museology was closed. Partly due to losing its attraction after the fall of the communist regime, when this occasion was no longer the sole opportunity for the East and West to meet, but also due to gross organisational and personal negligence in 2000-2002. Unfortunately, Brno abandoned this tradition when similar summer schools were being established in other countries (Celje in Slovenia, Amsterdam in the Netherlands, Graz in Austria, Baltic countries). Examples from abroad are very important and necessary, both in a positive or a negative, discouraging sense, but foreign production is not monitored much in our countries. For instance, what is undoubtedly a high-quality magazine "Nordisk Museologi" is not subscribed to by anybody in the former Czechoslovakia. ${ }^{3}$ Brno's museology department does not subscribe to any magazine. On the other hand, it is not easy at all to get through ICOFOM production and to separate the wheat from the chaff, and the recently updated Curriculum Guidelines of ICTOP Committee cannot help much. Nevertheless, we can also find more than one good work throughout the large world museology production, so it is worth while keeping track.

The Czech and Slovak museum world seems to reflect the situation in museology. Years after 1989 showed a quantitative development of museums, omissions in registration, storage and care standards concerning the physical condition of collections were improved. Exhibitions abroad or in cooperation with foreign partners (often non-European) became more customary. Permanent and large exhibitions are built, sometimes of very high quality. It is worth mentioning at least a permanent exhibition of the Technical Museum in Brno, awarded in "The Best in Heritage" competition in 2006, which is held regularly in Dubrovnik in Croatia. After premature refusal of "documentation of contemporaneity" (called somewhat unpleasantly - documentation of socialism - that time in our country) just after 1989, museum workers are slowly coming back to those topics today, which is documented by the fourth symposium dedicated to this issue, organised by the Technical Museum in Brno in 2007. Lectures from these symposia are regularly published in special anthologies (the last one was Störová 2007). The requirement for documentation of minorities is accelerated (Veselská 2006), or review of the approach to public needs, fortunately not in an exaggerated attempt, as we can see in many other countries (Appleton 2001). The framework of the Central European area is exceeded by unique projects, such as the Methodological Centre of Conservation, being established at the Technical Museum in Brno. ${ }^{4}$ Our museum world is mostly lucky to avoid the hopeless attempts to be "in", according to the popular US motto "not only museum" or recently finished voting megalomania trying to find the new seven wonders of the world.

Contrary to Hérakleitos, sometimes we seem to always step into the same river. Generation exchange in Czech and Slovak museums results in the recruitment of new people who might be good experts in their beloved history or ethnology, but as museum professionals they are absolute amateurs and often deny 


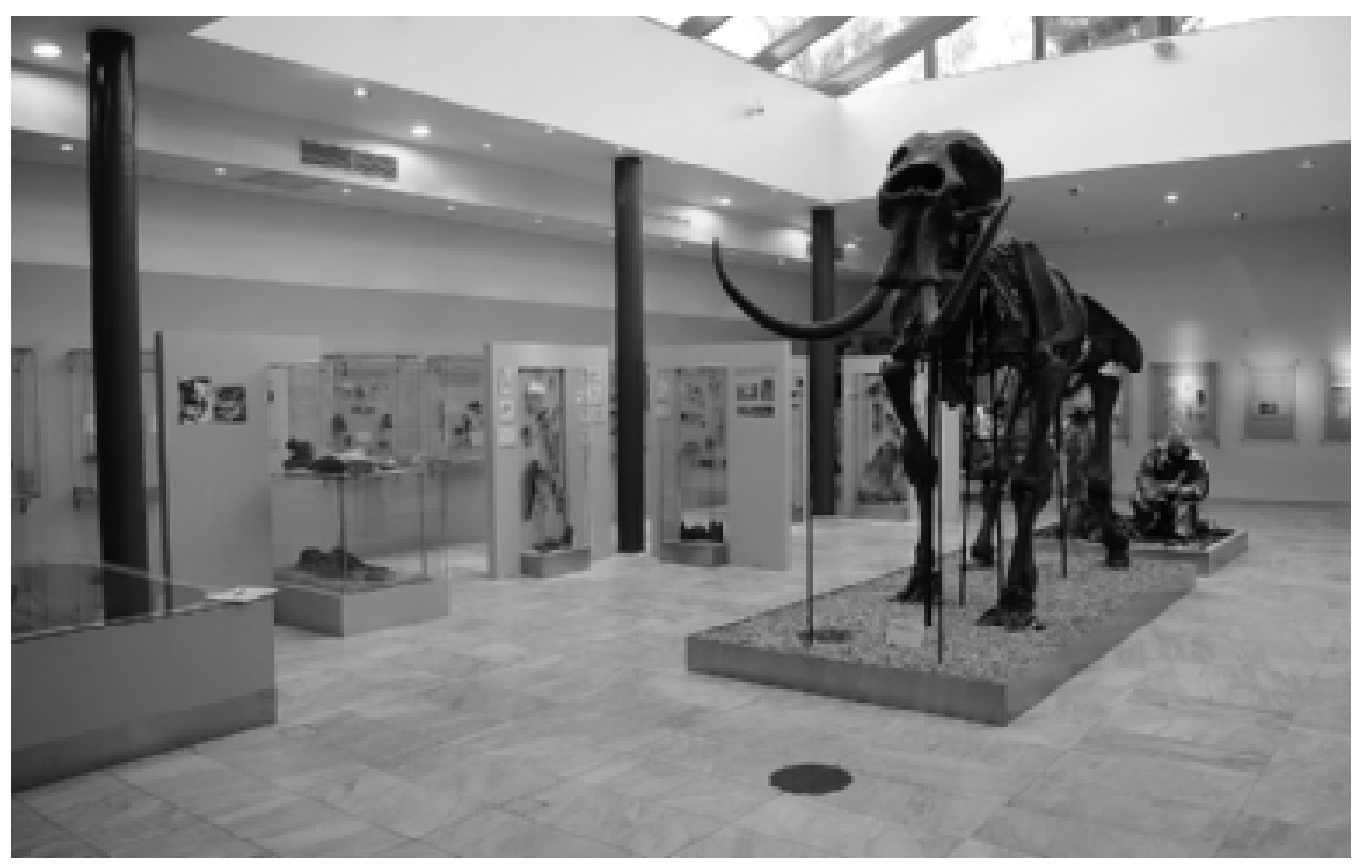

Fig. 2. New exhibition in Anthropos, a part of the Moravian regional museum in Brno.

their need for any further education in museology or at least in methods and technologies of museum work.

For describing any phenomenon, we must use the same or at least similar language, which is not easy in museology. If we refuse the opinion that museology is a real science (very rare) or complete nonsense (not a rare opinion at all, indeed), then we reach a dual approach. Museology as a package of methods and techniques needed for working in a museum (preservation, marketing, working with the public, etc.), means museography on one hand and museology as an independent discipline solving issues of museality, musealisation of the world etc., on the other hand. From this point of view, Czech and Slovak museography is going quite well. New works from the history of museum culture development have appeared; we are very active in the field of preservation and also in other fields, including topics not mentioned or even tabooed in the past in our country, such as German (Kirsch 2007) or Ukrainian museums (Dolák 2006).

Great steps have been made in standardization of museums, revolutionary in registration of the collection fund. Czech museologists give presentations and publish within ICOM Committees (Juracková 2006) or elsewhere (Jirásek 2004). Bibliographical works focused on collecting the production of leading museologists (Dolák, Vavríková 2006) are published. Museological issues incl. monitoring of the educational process are discussed at international conferences, e.g. Museum and 
JAN DOLÁK

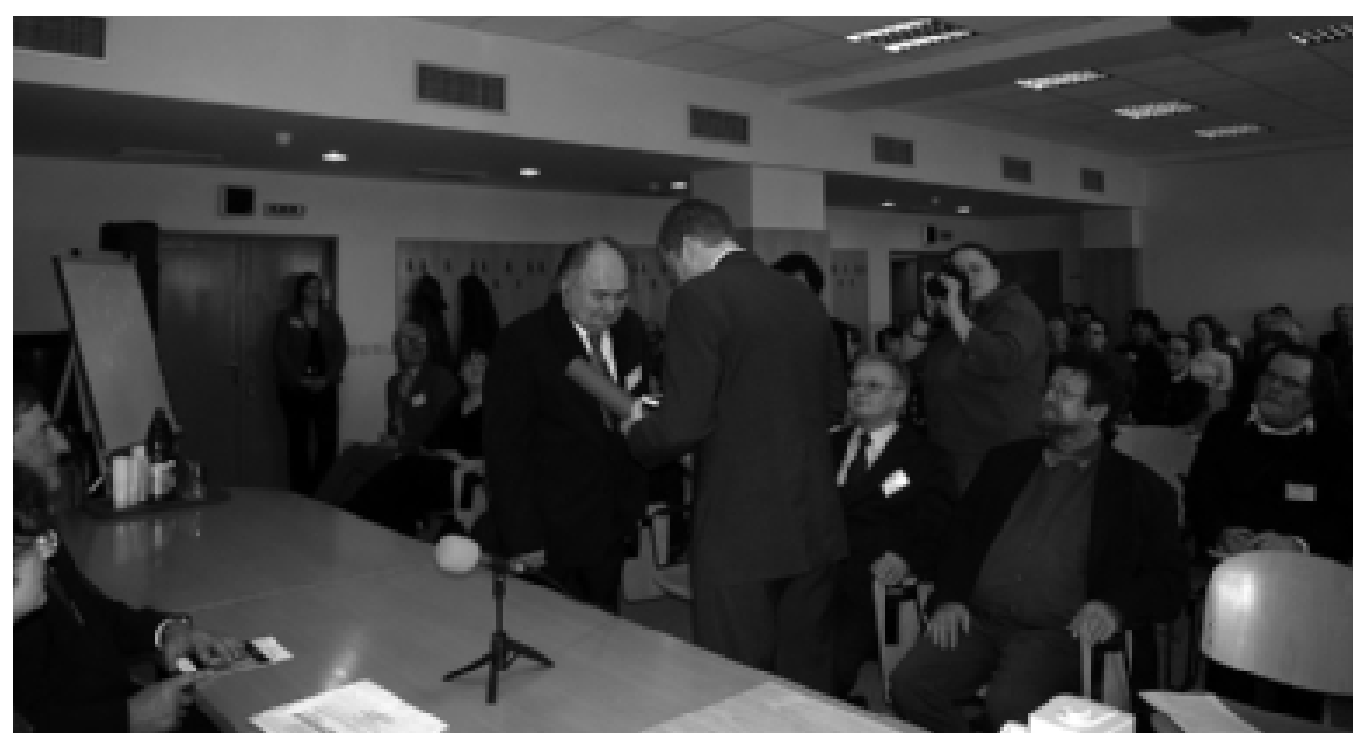

Fig. 3. Rector of Masaryk University Petr Fiala gives the Silver medal of MU to Zbynek Zbyslav Stransky for his lifework. Brno, the Technical museum, November 8 2006, International symposium "Musealization in contemporary society and role of museology".

Change, Musealization in Contemporary Society and the Role of Museology (in press) or Museums in Transformation Process ( Dolák 2004) organised by the Association of $\mathrm{Mu}$ seums and Galleries of the Czech Republic or Brno's UNESCO Chair. However, a really theoretic attitude to this issue is quite rare. Anyway, it is not easy to find a suitable platform for publication of articles about museology, even if the situation in Slovakia seems to be obviously better. Thanks to the Slovakian National Museum in cooperation with the Association of Slovak Museums, the professional magazine "Múzeum" is distributed in Bratislava, whilst colleagues from Banská Bystrica regularly publish on the pages of "Acta Museologica" and from Nitra in "Studia Historica Nitriensia". Traditional periodicals of similar orientation in the Czech Republic, e.g. Pragu- e's "Museal and Homeland Study" are fully in the hands of the branches cultivated in museums (in this case, archaeology and history) and there is a lack of space for museology production.

World museology, together with the theory of this branch, could be compared in the style of Peter Vergo to Coelacanth “ ... that remarkable creature whose brain, in the course of its development from embryo to adult, shrinks in relation to its size, so that in the end it occupies only a fraction of the space available to it. Unless a radical re-examination of the role of museums within society - by which I do not mean measuring their success merely in terms of criteria such as more money and more visitors - takes place, museums in this country, and possibly elsewhere, may likewise find themselves dubbed living fossils" (Vergo 
2000: 3-4). The number of museums or facilities of the museum (body) type is undoubtedly increasing in the world, but the mentioned brain is not so well developed. I am for more extensive education of museum workers in management, marketing and museum pedagogy, but this is will not solve everything. First of all, these workers must recognize which documents of society and natural development should be recorded, musealized (Theory of Selection), defend them against the nature of cessation (Theory of Thesauration) and using an appropriate form, present them to the public (Theory of Presentation). Such knowledge can be achieved only through the study of museology.

If we wish to categorize current Czech and Slovak museology and especially museography into a larger European or even world framework, it is rather above standard in the world and also not lost within the European context. In my opinion, the Czech and Slovak environment however, is not a pioneer in this branch as it was not long ago. Looking at the future of this branch, in general it is necessary to improve the level of museology, including its teaching and practical impact on the museum environment, and in a more detailed view, to initiate and establish a museology magazine in the Czech Republic.

\section{Notes}

1. I thank P. Holman, my colleague, for providing me with these summaries.

2. Presentation of M. Stehlík, Dean of the Faculty of Philosophy and Arts, Charles University in Prague, at the conference "Museology in theory and practice", a meeting of museology teachers held in Brno on 16-17 October 2007.
3. I thank Mrs. Ane Hejlskov Larsen for providing me with the information.

4. See the lecture "Cultural heritage and its conservation" by the author of this article, presented at the conference "A Contemporary Look on the Preservation of Cultural Heritage" on 3rd October 2007 in Rio de Janeiro, Brazil (in press) or his presentation in Wellington, New Zealand, at the session of the NATHIST Committee in December 2006, available on: http://www.icomnathist.de/icom/nl_21_dolak.htm.

\section{LITERATURE:}

APPLETON, Josie, et al. Museums for "The People"? 1st edition London: Academy of Ideas, 2001. 54 p. ISBN 1-904025-01-3.

DOLÁK, Jan, et al. Museums in Transformation Process. Dolák Jan. 1st edition Brno: Masaryk University, 2004. 203 p., VIII. ISBN 80-210-35943.

DOLÁK, Jan. Muzejní dokumentace menšin doma i v zahranicí. In VESELSKÁ, Dana. Thesauration and presentation of the cultural heritage of minorities in the collections and exhibition programmes of museums and galleries. 1st edition Prague: Jewish Museum in Prague, 2006. p. 21-36. ISBN 8086889-42-4.

DOLÁK, Jan, VAVRÍKOVÁ, Jana. Muzeolog Z.Z.Stránský : ivot a dílo. 1st edition Brno: Masaryk University, 2006. 59 p. ISBN 80-2104139-0.

JIRÁSEK, Pavel. Museum Security and Disaster Preparedness. In BOYAN, Partick J. Running a Museum: A Practical Handbook. 1st edition. Paris: ICOM, 2004. p. 177-195. ISBN 92-9012-157-2. JURACKOVÁ, Simona. Between Local and International. In MORK, Paal. Diverse Cultures-Diverse Communications. 1st edition. Oslo : [s.n.], 2006. p. 19-21. 
106 KIRSCH, Otakar. Formy spolupráce ceských a nemeckých muzejníku (na príkladu Moravy). In COUFALOVÁ, Iveta. Identita versus integrita II.: Spolu ití Cechu, Nemcu a idu (nejen) v oblasti Šumavy a Ceského lesa.. 1st edition Plzen: [s.n.], 2007, p. 171-178. ISBN 978-80-87046-12-8.

Muzeológia - teória a prax : Zborník príspevkov z muzeologickej konferencie. Hrcka Michal; Krišková Zdena. 1st edition Banská Štiavnica : Spolocnost'pre pamiatky, 2006. 156 p. ISBN 80969561-7-5.

STRÁNSKÝ, Zbynek Zbyslav. Archeologie a muzeologie. 1st edition Brno: Masaryk University in Brno, 2005. 315 p. ISBN 80-210-3861-6.

Teorie a praxe - dokumentace spolecnosti : Sbornik z odborného semináre. Pavla Stöhrová. 1st edition Brno: Technical Museum in Brno, 2007. 89 p. ISBN 80-86413-40-3.

VERGO, Peter. The New Museology. 1st edition London: Reaction Books, 2000. 230 p. ISBN O948462-03-5.

VESELSKÁ, Dana. Thesauration and presentation of the cultural heritage of minorities in the collections and exhibition programmes of museums and galleries. 1st edition Prague: Jewish Museum in Prague, 2006. p. 130. ISBN 80-86889-42-4.

*PhD. Jan Dolák

The Chairholder of the UNESCO Chair of Museology and World Heritage.

Address: Arna Nováka 1, Faculty of Arts, Masaryk university, tel.: +420549493470, fax: +420549491557, e-mail:dolak@phil.muni.cz,web: www.phil.muni.cz/unescol

A museologist and lecturer in collection management, management and marketing of museums and the history of Czech museums. He was born in 1962, studied history and museology at Brno University, then became manager of a few Czech museums. Former President of the Czech Association of Museums and Galleries. He is a member of the International Council of $M u$ seums, member of the Executive Board of ICOFOM. He has been working at Masaryk University since 2001 and is a visiting lecturer both at home and abroad.

He has organized some international conferences. He is currently preparing an extensive work about Communication of Archaeology. He is interested in documentation of the present time, documentation of minorities and archaeological exhibitions.

More: 1. www.muni.cz/people/69885/teaching

2. www.muni.cz/people/69885/publications

3. www.phil.muni.cz/unescol

4. http://www.connectcp.org/profiles/ profile.php?profileid $=174$

5. http://www.museumaktuell.delindex.php (wissenschaftler,museologen) 